\title{
Wpływ wybranych czynników na sposób postrzegania osób chorych na schizofrenię
}

\section{The influence of selected factors on the perception of people with schizophrenia}

\author{
ADRIANNA FRYDRYSIAK ${ }^{1}$ \\ 1 Państwowa Wyższa Szkoła Zawodowa w Płocku, Wydział Nauk o Zdrowiu, Zakład \\ Pielęgniarstwa \\ DOI: http://dx.doi.org/10.21784/IwP.2018.003 \\ ISSN: 2541-1846
}

\section{Streszczenie:}

Wstęp. Schizofrenia jest chorobą psychiczną, która wymagająca długofalowego leczenia. Brak wsparcia ze strony otoczenia oraz stygmatyzacja potęgują konsekwencje choroby.

Cel. Celem niniejszej pracy jest analiza postrzegania osób chorych na schizofrenię przez studentów studiów licencjackich na kierunku pielęgniarstwo oraz pielęgniarki czynne zawodowo.

Materiał i metody. Dla potrzeb pracy zastosowano metodę sondażu diagnostycznego i technikę ankiety. Kwestionariusz zawierał dwadzieścia trzy pytania.

Wnioski. W zawodzie pielęgniarki doświadczenie zawodowe nie ma istotnego wpływu na zmianę postrzegania osób chorych na schizofrenię. W zawodzie pielęgniarki poziom wykształcenia ma istotny wpływ na postrzeganie osób chorych na schizofrenię. Częstotliwość spotkań z chorymi na schizofrenię ma istotny wpływ na sposób ich postrzegania.

Słowa kluczowe: schizofrenia, postrzeganie

Abstract: 
Introduction. Schizophrenia is a mental disorder that requires long-term treatment. Lack of support from the environment and stigmatisation intensify the consequences of the disease.

Aim. The purpose of this master's dissertation is the analysis of how professionally active nurses and nursing students of bachelor degree perceive patients suffering for schizophrenia.

Material and methods. For this master's dissertation a diagnistic survey and a questionnaire were used. The interviewees had to give answers to questions. The questionnaire contained twenty-three questions.

Conclusions. In nursing profession work experience does not have significant influence on the change of perception of patients suffering from schizophrenia. However, the level of education affects the perception of patients suffering from schizophrenia. The frequency of interaction with schizophrenia patients has got significant impact on how they are perceived.

Keywords: schizophrenia, perception

\section{Wstęp}

Zaburzenia psychiczne są istotną kwestią zdrowotną, z których zdaniem specjalistów najpoważniejszą chorobę stanowi schizofrenia. Opisywana jest jako chroniczna choroba psychiczna, wymagająca kompleksowego, długofalowego leczenia, która zakłócając stan równowagi organizmu, odbija się ujemnie na prawidłowym funkcjonowaniu jednostki [1-3]. Schizofrenia stanowi problem kliniczny i społeczny, dotycząc aktualnie do półtora procent populacji generalnej. Brak jest wskaźników różnicujących występowanie schizofrenii pomiędzy poszczególnymi rasami i płciami. Faktem jest, że mężczyźni na schizofrenię zapadają w młodszym wieku (15-25 r. ż.) i mają bardziej burzliwy przebieg choroby. Kobiety przechodzą ją łagodniej, najprawdopodobniej dzięki ochronnej działalności estrogenów. Zapadają na nią w późniejszym wieku, pomiędzy 15-45 r.ż. Incydentalnie choroba zaczyna rozwijać po 45 r.ż. lub w dzieciństwie [4,5,6]. Dwukrotnie częściej od osób owdowiałych i pozostających w związkach chorują osoby samotne i rozwiedzione. 
Jednocześnie osoby cierpiące na schizofrenię najczęściej wywodzą się $\mathrm{z}$ niższych klas społecznych co wiąże się $\mathrm{z}$ ich podwyższoną predyspozycją do degradacji społecznej. Szacuje się, że powyżej $50 \%$ chorych na schizofrenię uzależnionych jest od nikotyny, alkoholu lub marihuany $[4,7,8]$.

Przewlekły przebieg choroby, wielokrotnie powtarzające się hospitalizacje generują deficyty $\mathrm{w}$ zakresie funkcjonowania społecznego. Brak wsparcia ze strony otoczenia, jego bezradność i stygmatyzacja połączona $\mathrm{z}$ przejawami dyskryminacji potęgują konsekwencje choroby $[9,10]$.

Proces spostrzegania, inaczej percepcji określany jest jako proces poznawczy związany $\mathrm{z}$ przetwarzaniem informacji sensorycznej pod wpływem zadziałania bodźców. Do świadomości człowieka dociera tylko nikła ilość bodźców, oddziałujących w danej chwili na jednostkę, co wynika $\mathrm{z}$ ograniczonych indywidualnych możliwości percepcyjnych. Są to bodźce najsilniejsze, oczekiwane lub związane z subiektywnymi emocjami jednostki. Nie tylko bodźce fizyczne wpływają na spostrzeganie. Może być ono również wynikiem procesów emocjonalnych, intuicji i myślenia $[11,12]$.

\section{Obraz osoby chorej na schizofrenię w opinii społeczeństwa}

$\mathrm{Na}$ podstawie badań przeprowadzonych przez Centrum Badania Opinii Społecznej w 2008 roku osoby chore psychicznie utożsamiane są $\mathrm{z}$ osobami upośledzonymi umysłowo lub niedorozwiniętymi (24\%). Ankietowani określają je również jako trudne do zniesienia, niebezpieczne, nieprzewidywalne i niepoczytalne (39\%). Polacy w kontaktach $\mathrm{z}$ chorymi psychicznie rodakami niejednokrotnie odczuwają litość, strach i bezradność, co wynika z pobieżnego przygotowania do spotkania i niewiedzy $[13,14]$. Jednocześnie $44 \%$ badanych nie odczuwa potrzeby jej pogłębienia, przy $8,5 \%$ którzy deklarowali chęć nauki $[15,16]$. Na podstawie badań przeprowadzonych w 14 krajach europejskich ocena społeczna 
najniżej z chorób psychicznych plasuje diagnozę schizofrenii. Krzywdzące i niesłuszne stereotypy dotyczące chorujących na schizofrenię doprowadzają do tego, że najbliższa rodzina pozostaje niejednokrotnie jedyną grupą uczestniczącą w życiu osoby chorej. Wspierającą ją ekonomicznie i emocjonalnie. Społeczne wykluczenie dotyczy głównie chorujących na schizofrenię i psychozy ponad 6 lat, niepracujących i pobierających rentę inwalidzką $[17,18]$.

Znaczny wpływ na ukształtowanie stosunku wobec osób chorujących na schizofrenię mają powszechne media. Przedstawiając je jako nieprzewidywalne i niesympatyczne, niezdolne do produktywnej pracy, silnie związane z przemocą. Brak akceptacji opiera się na istnieniu błędnych stereotypów, zgodnie z którymi schizofrenia to choroba nieuleczalna, przebiegająca zawsze niekorzystnie. Zaś osoby na nią chorujące mogą swoim szaleństwem zarażać innych [1,17]. Stygmatyzacja osób chorych na schizofrenię prowadzi do postrzegania jej jako osoby gorszej od ogółu. Dezaprobata i negatywny odbiór tej grupy społecznej prowadzi do coraz większego dystansowania się chorych i ich rodzin [19,20]. Źródłem napiętnowania ze strony społeczeństwa stają się objawy schizofrenii odbijające się na zachowaniu chorego. Można do nich zaliczyć napięcie, wycofanie emocjonalne, halucynacje, podejrzliwość, agresję, czy próby samobójcze. Duże znaczenie w ocenie chorującej jednostki ma również jakość wyglądu zewnętrznego, wpływając pozytywnie lub negatywnie na nadszarpnięte relacje społeczne [18].

Porównując dane z 1999r. z Komunikatem z badań „Osoby chore psychicznie w społeczeństwie” z 2008r., przeprowadzonego przez CBOS można wspomnieć o pogorszeniu się stosunku badanych do chorych psychicznie. Nastąpił spadek liczby osób traktujących ich życzliwie wraz ze wzrostem odczuwających obojętność. Poziom niechęci pozostał na niezmienionym poziomie. Życzliwość wobec chorych psychicznie rośnie wraz z wiekiem. Najniższą odnotowano u respondentów najmłodszych $\mathrm{w}$ wieku 18-24 lata. Pozytywniejszy 
stosunek deklarują również kobiety, kadra kierownicza oraz osoby zaangażowane $w$ wyznania religijne [21].

Celem niniejszej pracy jest analiza postrzegania osób chorych na schizofrenię przez studentów studiów licencjackich na kierunku pielęgniarstwo oraz pielęgniarki czynne zawodowo.

\section{Materiał i metody}

Badania przeprowadzono w okresie od 26 kwietnia 2016 roku do 20 lipca 2016 roku w grupie 50 studentów kierunku pielęgniarstwo Państwowej Wyższej Szkoły Zawodowej w Płocku oraz wśród 44 czynnych zawodowo pielęgniarek/pielęgniarzy Wojewódzkiego Samodzielnego Zespołu Publicznych Zakładów Opieki Zdrowotnej w Gostyninie.

W niniejszej pracy problemem głównym było określenie potencjalnych różnic $\mathrm{w}$ postrzeganiu osób chorych na schizofrenię przez pielęgniarki pracujące zawodowo i studentów studiów licencjackich na kierunku pielęgniarstwo.

W ramach przytoczonego problemu głównego, wyodrębniono następujące problemy szczegółowe:

1. Czy w zawodzie pielęgniarki doświadczenie zawodowe wpływa na sposób postrzegania osób chorych na schizofrenię?

2. Czy w zawodzie pielęgniarki wykształcenie wpływa na sposób postrzegania osób chorych na schizofrenię?

3. Czy częsty kontakt z osobami chorymi na schizofrenię zmienia profil ich postrzegania?

Dla potrzeb pracy zastosowano metodę sondażu diagnostycznego, technikę ankietową, zaś narzędziem badawczym był kwestionariusz ankiety, który zawierał dwadzieścia trzy pytania.

Badając odpowiedzi każdej z grup respondentów wyznaczono średnią wyników oraz odchylenie standardowe. Dla określenia wzajemnych powiązań pomiędzy zmiennymi (odpowiedzi grupy studentów i pielęgniarek/pielęgniarzy) wykorzystano 
znormalizowany współczynnik korelacji przybierający wartości od -1 (zupełna korelacja ujemna), przez 0 (brak korelacji) do +1 (zupełna korelacja dodatnia) oraz test Chi - kwadrat $\left(\mathrm{X}^{2}\right)$.

Tabela 1. Podział respondentów ze względu na wiek.

\begin{tabular}{|l|l|l|l|l|l|l|}
\hline \multirow{2}{*}{ Wiek } & \multicolumn{2}{|l|}{ Studenci } & \multicolumn{2}{l|}{ Pielęgniarki/Pielęgniarze } & \multirow{2}{*}{ Ogółem } & \multirow{2}{*}{$\%$} \\
\cline { 2 - 7 } & Liczba & $\%$ & Liczba & \% & & \\
\hline 20 - 29 lat & 47 & 94 & 3 & 7 & 50 & 53 \\
\hline 30 - 39 lat & 3 & 6 & 9 & 20 & 12 & 13 \\
\hline $40-49$ lat & 0 & 0 & 24 & 55 & 24 & 26 \\
\hline 50 - 59 lat & 0 & 0 & 8 & 18 & 8 & 8 \\
\hline 60 i więcej & 0 & 0 & 0 & 0 & 0 & 0 \\
\hline suma & 50 & 100 & 44 & 100 & 94 & 100 \\
\hline
\end{tabular}

Źródło: wynik badań własnych.

Badaniem objęto 94 osoby w wieku od 20 do 59 lat.

Tabela 2. Podział badanych pielęgniarek/pielęgniarzy ze względu na staż pracy.

\begin{tabular}{|l|l|l|}
\hline Staż pracy & Liczba & $\%$ \\
\hline Poniżej roku & 0 & 0 \\
\hline $1-5$ lat & 3 & 7 \\
\hline $6-10$ lat & 3 & 7 \\
\hline $11-15$ lat & 7 & 16 \\
\hline $16-20$ lat & 12 & 27 \\
\hline Powyżej 20 lat & 19 & 43 \\
\hline suma & 44 & 100 \\
\hline
\end{tabular}

Źródło: wynik badań własnych.

Wśród pielęgniarek/pielęgniarzy $43 \%$ stanowiły osoby z ponad 20-letnim stażem pracy, $27 \%$ ze stażem z przedziału $16-20$ lat, zaś $16 \%$ z przedziału 11-15 lat. Tylko 14\% miało staż pracy mniejszy niż 10 lat. Można, więc stwierdzić, że grupa pielęgniarek 
i pielęgniarzy charakteryzowała się dużym doświadczeniem zawodowym.

Tabela 3. Podział ankietowanych pielęgniarek/pielęgniarzy uwzględniający wykształcenie.

\begin{tabular}{|l|l|l|}
\hline Ukończona szkoła & Liczba & $\%$ \\
\hline Studium medyczne & 15 & 34 \\
\hline Liceum medyczne & 4 & 9 \\
\hline Studia licencjackie & 19 & 43 \\
\hline Studia magisterskie & 6 & 14 \\
\hline suma & 44 & 100 \\
\hline
\end{tabular}

Źródło: wynik badań własnych

Wśród ankietowanych pielęgniarek/pielęgniarzy najliczniejszą grupę tj. 19 osób (43\%) stanowili absolwenci studiów licencjackich, zaś 6 osób tj. 14\% uzyskało tytuł magistra. Studium medyczne ukończyło $34 \%$ przebadanych pielęgniarek/pielęgniarzy. Tylko 9\% zakończyło naukę po uzyskaniu świadectwa liceum medycznego.

Tabela 4. Deklarowany przez respondentów kontakt z osobami chorymi na schizofrenię.

\begin{tabular}{|c|c|c|c|c|c|c|}
\hline \multirow{2}{*}{$\begin{array}{lr}\text { Jak często ma } & \text { Pani/Pan } \\
\text { kontakt z } & \text { osobami } \\
\text { chorymi } & \text { na } \\
\text { schizofrenię? } & \end{array}$} & \multicolumn{2}{|c|}{ Studenci } & \multicolumn{2}{|c|}{$\begin{array}{l}\text { Pielegniarki/ } \\
\text { Pielęgniarze }\end{array}$} & \multirow{2}{*}{ Ogółem } & \multirow{2}{*}{$\%$} \\
\hline & Liczba & $\%$ & Liczba & $\%$ & & \\
\hline Codziennie & 4 & 8 & 6 & 14 & 10 & 11 \\
\hline Kilka razy w tygodniu & 0 & 0 & 31 & 70 & 31 & 33 \\
\hline Kilka razy w miesiącu & 7 & 14 & 5 & 11 & 12 & 13 \\
\hline Raz na rok & 27 & 54 & 1 & 2 & 28 & 30 \\
\hline Nigdy & 12 & 24 & 1 & 2 & 13 & 14 \\
\hline suma & 50 & 100 & 44 & 100 & 94 & 100 \\
\hline
\end{tabular}

Źródło: wynik badań własnych. 
Wśród studentów przeważały osoby, które nigdy nie miały kontaktu z osobami chorującymi na schizofrenię -24\% (12 osób) lub miały kontakt raz na rok 54\% (27 osób). Pielęgniarki/pielęgniarze najczęściej zaznaczali odpowiedź świadczącą o częstym kontakcie z wymienionymi chorymi, tj. kilka razy w tygodniu 70\% (31 osób) lub codziennie 14\% (6 osób).

\section{Wyniki}

Tabela 5. Cechy chorego na schizofrenię wymieniane przez respondentów.

\begin{tabular}{|c|c|c|c|c|c|c|}
\hline \multirow{2}{*}{$\begin{array}{l}\text { Pani/Pana zdaniem cechy } \\
\text { chorego na schizofrenię to: }\end{array}$} & \multicolumn{2}{|c|}{ Studenci } & \multicolumn{2}{|c|}{$\begin{array}{l}\text { Pieleggniarki/ } \\
\text { Pielęgniarze }\end{array}$} & \multirow[t]{2}{*}{ Ogółem } & \multirow[t]{2}{*}{$\%$} \\
\hline & \begin{tabular}{|l|} 
Liczba \\
\end{tabular} & $\%$ & \begin{tabular}{|l|} 
Liczba \\
\end{tabular} & $\%$ & & \\
\hline Zachowanie niezrozumiałe & 14 & 28 & \begin{tabular}{|l|l|}
13 \\
\end{tabular} & 30 & 27 & 29 \\
\hline Zagubienie, bezradność & 16 & 32 & 10 & 23 & 26 & 28 \\
\hline $\begin{array}{l}\text { Nadpobudliwość, } \\
\text { agresywność }\end{array}$ & 12 & 24 & 13 & 30 & 25 & 27 \\
\hline Napięcie, lęk bez powodu & 18 & 36 & 22 & 50 & 40 & 43 \\
\hline $\begin{array}{l}\text { Nieufność, } \\
\text { w sobie }\end{array}$ & 24 & 48 & 12 & 27 & 36 & 38 \\
\hline $\begin{array}{l}\text { Bierność, } \quad \text { zobojętnienie } \\
\text { wobec własnego losu }\end{array}$ & 9 & 18 & 10 & 23 & 19 & 20 \\
\hline $\begin{array}{l}\text { Podszywanie się pod inną } \\
\text { osobę }\end{array}$ & 4 & 8 & 1 & 2 & 5 & 5 \\
\hline
\end{tabular}

Źródło: wynik badań własnych.

Najczęściej zaznaczanymi cechami chorego na schizofrenię były: „napięcie, lęk bez powodu” - 43\%wszystkich badanych oraz „nieuf ność, zamkniecie w sobie” - 38\% ogółu respondentów. Pierwszą $\mathrm{z}$ odpowiedzi wybierała przede wszystkim grupa pielęgniarzy/pielęgniarek, zaś drugą grupa studentów. Dość częstymi 
odpowiedziami były także: „zachowanie niezrozumiałe” i „zagubienie, bezradność" -odpowiednio po 29\% i 28\% oraz „nadpobudliwość, agresywność"- 27\%. Tylko 5\% wszystkich badanych określiło „podszywanie się pod inną osobę" jako cechę chorego na schizofrenię.

Tabela 6. Określenia chorych na schizofrenię oznaczane przez respondentów.

\begin{tabular}{|l|l|l|l|l|l|l|}
\hline \multirow{2}{*}{$\begin{array}{l}\text { Jak określiłaby Pani/Pan } \\
\text { osobę } \\
\text { chorą na schizofrenię? }\end{array}$} & \multicolumn{2}{l|}{ Studenci } & \multicolumn{2}{l|}{$\begin{array}{l}\text { Pielęgniarki/ } \\
\text { Pielęgniarze }\end{array}$} & \multirow{2}{*}{ ogółem } & $\%$ \\
\cline { 2 - 7 } $\begin{array}{l}\text { To normalny, dotknięty } \\
\text { chorobą człowiek }\end{array}$ & 31 & 62 & 31 & 70 & 62 & 66 \\
\hline Potencjalny przestępca & 0 & 0 & 0 & 0 & 0 & 0 \\
\hline Dziwak & 3 & 6 & 3 & 7 & 6 & 6 \\
\hline Psychol, świrus & 3 & 6 & 1 & 2 & 4 & 4 \\
\hline $\begin{array}{l}\text { Osoba nieprzewidywalna } \\
\text { niebezpieczna }\end{array}$ & 6 & 12 & 9 & 20 & 15 & 16 \\
\hline Nie mam zdania & 7 & 14 & 0 & 0 & 7 & 7 \\
\hline suma & 50 & 100 & 44 & 100 & 94 & 100 \\
\hline Zna & & & & & \\
\hline
\end{tabular}

Źródło: wynik badań własnych

2/3 wszystkich respondentów - 66\% uznało chorych na schizofrenię za normalnych, dotkniętych chorobą ludzi. Wśród pozostałych odpowiedzi, określenie „osoba nieprzewidywalna, niebezpieczna” uzyskało 16\%, „dziwak” - 6\%, „psychol, świrus” - 4\%. Nie miało na ten temat zdania $7 \%$ ankietowanych. Żadna z osób nie zaznaczyła określenia „potencjalny przestępca” .

Tabela 7. Odczucia respondentów wobec osoby, której zachowanie sugeruje, że choruje psychicznie. 


\begin{tabular}{|c|c|c|c|c|c|c|}
\hline \multirow{2}{*}{$\begin{array}{l}\text { Jakie odczucia dominują } w \\
\text { Pani/Panu wobec osoby, } \\
\text { której zachowanie sugeruje, } \\
\text { że choruje psychicznie? }\end{array}$} & \multicolumn{2}{|c|}{ Studenci } & \multicolumn{2}{|c|}{$\begin{array}{l}\text { Pielęgniarki/ } \\
\text { Pielęgniarze }\end{array}$} & \multirow{2}{*}{ Ogółem } & \multirow{2}{*}{$\%$} \\
\hline & Liczba & $\%$ & Liczba & $\%$ & & \\
\hline Akceptacja, życzliwość & 7 & 14 & 12 & 27 & 19 & 20 \\
\hline $\begin{array}{l}\text { Chęć niesienia pomocy, } \\
\text { przychylność }\end{array}$ & 20 & 40 & 20 & 45 & 40 & 43 \\
\hline Współczucie & 15 & 30 & 10 & 23 & 25 & 27 \\
\hline Obojętność & 0 & 0 & 0 & 0 & 0 & 0 \\
\hline Lęk, strach & 7 & 14 & 2 & 5 & 9 & 10 \\
\hline Fascynacja & 1 & 2 & 0 & 0 & 1 & 1 \\
\hline suma & 50 & 100 & 44 & 100 & 94 & 100 \\
\hline
\end{tabular}

Źródło: wynik badań własnych.

W odpowiedzi na powyższe pytanie (tabela 7), aż 43\% ankietowanych wyraziło chęć niesienia pomocy i przychylność wobec osób z zaburzeniami psychicznymi. Z kolei $27 \%$ odczuwało współczucie, a 20\% akceptację i życzliwość. Tylko 10\% zaznaczyło, że odczuwa strach i lęk, zaś 1osoba - fascynację.

Tabela 8. Optymalne miejsce pobytu osoby chorej na schizofrenię wyznaczone przez ankietowanych.

\begin{tabular}{|l|l|l|l|l|l|l|}
\hline \multirow{2}{*}{$\begin{array}{l}\text { Jako optymalne miejsce } \\
\text { osoby } \\
\text { chorej na schizofrenię } \\
\text { wyznaczyłaby Pani/Pan? }\end{array}$} & \multicolumn{2}{|l|}{ Studenci } & \multicolumn{2}{l|}{$\begin{array}{l}\text { Pielęgniarki/ } \\
\text { Pielęgniarze }\end{array}$} & ogółem & \multirow{2}{*}{$\%$} \\
\cline { 2 - 8 } & Liczba & $\%$ & Liczba & $\%$ & & \\
\hline Rodzinny dom & 35 & 70 & 31 & 70 & 66 & 70 \\
\hline Samodzielne mieszkanie & 0 & 0 & 2 & 5 & 2 & 2 \\
\hline Szpital psychiatryczny & 12 & 24 & 4 & 9 & 16 & 17 \\
\hline $\begin{array}{l}\text { Zamkniętą placówkę } \\
\text { opieki społecznej }\end{array}$ & 3 & 6 & 7 & 16 & 10 & 11 \\
\hline suma & 50 & 100 & 44 & 100 & 94 & 100 \\
\hline
\end{tabular}

Źródło: wynik badań własnych. 
Za optymalne miejsce dla osoby chorej na schizofrenię uznało dom rodzinny 60 (70\%) respondentów. Z kolei 17\% doszło do wniosku, że powinien to być szpital psychiatryczny, a 11\%, że zamknięta placówka opieki społecznej. Tylko $2 \%$ badanych twierdziło, że najlepszym miejscem dla $\mathrm{w} / \mathrm{w}$ chorych jest samodzielne mieszkanie.

Tabela 9. Opinia respondentów na temat problemów osób chorych na schizofrenię.

\begin{tabular}{|c|c|c|c|c|c|c|}
\hline \multirow{2}{*}{\begin{tabular}{l}
\multicolumn{3}{|l|}{ Pani/Pana zdaniem co } \\
najbardziej \\
życie osobie chorej na \\
schizofrenię?
\end{tabular}} & \multicolumn{2}{|c|}{ Studenci } & \multicolumn{2}{|c|}{$\begin{array}{l}\text { Pielęgniarki/ } \\
\text { Pielęgniarze }\end{array}$} & \multirow{2}{*}{ Ogółem } & \multirow{2}{*}{$\%$} \\
\hline & Liczba & $\%$ & Liczba & $\%$ & & \\
\hline $\begin{array}{l}\text { Zależność od leków } \\
\text { psychotropowych }\end{array}$ & 6 & 12 & 13 & 30 & 19 & 20 \\
\hline $\begin{array}{l}\text { Nietolerancja, brak } \\
\text { zrozumienia } \\
\text { społecznego }\end{array}$ & 25 & 50 & 18 & 41 & 43 & 46 \\
\hline $\begin{array}{l}\text { Samotność, izolacja } \\
\text { społeczna }\end{array}$ & 8 & 16 & 6 & 14 & 14 & 15 \\
\hline $\begin{array}{l}\text { Poczucie bycia innym, } \\
\text { stygmatyzacja }\end{array}$ & 7 & 14 & 7 & 16 & 14 & 15 \\
\hline $\begin{array}{l}\text { Lęk i bariery } \\
\text { psychologiczne }\end{array}$ & 4 & 8 & 0 & 0 & 4 & 4 \\
\hline suma & 50 & 100 & 44 & 100 & 94 & 100 \\
\hline
\end{tabular}

Źródło: wynik badań własnych.

Jako cechę najbardziej utrudniającą życie chorym na schizofrenię ankietowani wskazali „nietolerancję, brak zrozumienia społecznego". Odpowiedziało tak 46\% wszystkich badanych. Drugą, co do częstości wybieranych odpowiedzi była „zależność od leków psychotropowych” - 20\%. Kolejne cechy to: „poczucie bycia innym, stygmatyzacja” oraz „samotność, izolacja społeczna”, które uzyskały 
po 15\% odpowiedzi. Najrzadziej zaznaczaną cechą był „lęk i bariery psychologiczne", którą zaznaczyło tylko 4\% badanych.

\section{Analiza statystyczna}

\section{Wpływ doświadczenia zawodowego $w$ zawodzie pielęgniarki na postrzeganie osób chorych na schizofrenię}

Dla zbadania pierwszej hipotezy podzielono ankietowane pielęgniarki/pielęgniarzy na 6 grup wiekowych i przeanalizowano ich odpowiedzi na trzy pytania (Tabela 6, Tabela 7, Tabela 8). Następnie zbadano korelację oraz poziom istotności między grupami różniącymi się stażem pracy. Wyniki przedstawiono w poniższej tabeli 10.

Tabela 10. Analiza statystyczna wpływu doświadczania zawodowego $w$ zawodzie pielęgniarki na postrzeganie osób chorych na schizofrenię.

\begin{tabular}{|c|c|c|c|c|c|c|c|c|c|c|c|c|c|c|c|c|c|c|c|}
\hline \multirow{2}{*}{$\begin{array}{l}\text { Staż } \\
\text { pracy }\end{array}$} & \multicolumn{6}{|c|}{ Pytanie 13} & \multicolumn{6}{|c|}{ Pytanie 14} & \multicolumn{4}{|c|}{ Pytanie 20} & \multirow{2}{*}{$\mathbf{N}$} & \multirow{2}{*}{$\begin{array}{l}\text { Wspót. } \\
\text { korelacji }\end{array}$} & \multirow{2}{*}{\begin{tabular}{|l|} 
Poziom \\
istotności \\
testu Chi \\
- kwadrat \\
\end{tabular}} \\
\hline & $\mathbf{A}$ & B & $\mathbf{C}$ & & $\mathbf{E}$ & $\mathbf{F}$ & $\mathbf{A}$ & $\mathbf{B}$ & $\mathbf{C}$ & D & & $\mathbf{F}$ & $\mathbf{A}$ & B & C & D & & & \\
\hline $\begin{array}{l}\text { Poniżej } \\
\text { roku }\end{array}$ & 0 & 0 & 0 & 0 & 0 & 0 & 0 & 0 & 0 & 0 & 0 & 0 & 0 & 0 & 0 & 0 & 0 & \multirow{6}{*}{0,634} & \multirow{6}{*}{0,0574} \\
\hline 1 - 5 lat & 1 & 0 & 1 & 0 & 1 & 0 & 1 & 1 & 1 & 0 & 0 & 0 & 2 & 0 & 0 & 1 & 3 & & \\
\hline $6-10$ lat & 3 & 0 & 0 & 0 & 0 & 0 & 1 & 2 & 0 & 0 & 0 & 0 & 1 & 0 & 1 & 1 & 3 & & \\
\hline $\begin{array}{l}11-15 \\
\text { lat }\end{array}$ & 3 & 0 & 1 & 0 & 3 & 0 & 0 & 2 & 5 & 0 & 0 & 0 & 4 & 0 & 0 & 3 & 7 & & \\
\hline $\begin{array}{l}16-20 \\
\text { lat }\end{array}$ & 9 & 0 & 0 & 1 & 2 & 0 & 4 & 6 & 1 & 0 & 1 & 0 & $\begin{array}{l}1 \\
1\end{array}$ & 0 & 0 & 1 & 12 & & \\
\hline $\begin{array}{l}\text { Powyżej } \\
20 \text { lat }\end{array}$ & $\begin{array}{l}1 \\
5\end{array}$ & 0 & 1 & 0 & 3 & 0 & 6 & 9 & 3 & 0 & 1 & 0 & $\begin{array}{l}1 \\
3\end{array}$ & 2 & 3 & 1 & 19 & & \\
\hline
\end{tabular}

Źródło: wynik badań własnych.

Otrzymany testem Chi - kwadrat wynik poziomu istotności jest większy od przyjętego $(p>0,05)$. Cecha badana, jaką jest doświadczenie zawodowe, okazała się nieistotna dla wyników pomiaru. Wyznaczony współczynnik korelacji jest w przedziale korelacji dodatniej przeciętnej 
$(0,634)$, co wskazuje na przeciętne podobieństwo odpowiedzi grup o różnym stażu pracy.

\section{Wpływ wykształcenia w zawodzie pielęgniarki na postrzeganie osób chorych na schizofrenię}

Przy badaniu powyższej hipotezy ankietowana grupa 44 pielęgniarek/pielęgniarzy została podzielona na podgrupy w zależności od wykształcenia. Następnie przeanalizowano odpowiedzi tej grupy na trzy pytania (Tabela 6, Tabela 7, Tabela 8). Wyniki przedstawiono w poniższej tabeli 11.

Tabela 11. Analiza statystyczna wpływu poziomu wykształcenia zawodowego $w$ zawodzie pielęgniarki na postrzeganie chorych na schizofrenię.

\begin{tabular}{|c|c|c|c|c|c|c|c|c|c|c|c|c|c|c|c|c|c|c|c|}
\hline \multirow{2}{*}{$\begin{array}{l}\text { Rodzaj } \\
\text { ukończonej } \\
\text { szkoły }\end{array}$} & \multicolumn{6}{|c|}{ Pyt. 13} & \multicolumn{6}{|c|}{ Pyt. 14} & \multicolumn{4}{|c|}{ Pyt. 20} & \multirow[b]{2}{*}{$\mathbf{N}$} & \multirow{2}{*}{$\begin{array}{l}\text { Wsp. } \\
\text { korelac } \\
\text { ji }\end{array}$} & \multirow{2}{*}{$\begin{array}{l}\text { Poziom } \\
\text { istotnośc } \\
\text { i testu } \\
\text { Chi } \quad- \\
\text { kwadrat }\end{array}$} \\
\hline & A & B & C & D & $\mathbf{E}$ & $\mathbf{F}$ & $\mathbf{A}$ & B & C & D 1 & & $\mathbf{F}$ & A & B & C & D & & & \\
\hline $\begin{array}{l}\text { Studium } \\
\text { medyczne }\end{array}$ & $\begin{array}{l}1 \\
2\end{array}$ & 0 & 1 & 0 & 2 & 0 & 6 & 7 & 2 & 0 & 0 & 0 & $\begin{array}{l}1 \\
1\end{array}$ & 0 & 2 & 2 & $\begin{array}{l}1 \\
5\end{array}$ & \multirow{4}{*}{0,314} & \multirow{4}{*}{0,018} \\
\hline $\begin{array}{l}\text { Liceum } \\
\text { medyczne }\end{array}$ & 2 & 0 & 0 & 1 & 1 & 0 & 0 & 0 & 3 & 0 & 1 & 0 & 2 & 0 & 1 & 1 & 4 & & \\
\hline Studia lic. & $\begin{array}{l}1 \\
4\end{array}$ & 0 & 1 & 0 & 4 & 0 & 3 & $\begin{array}{l}1 \\
1\end{array}$ & 5 & 0 & 0 & 0 & $\begin{array}{l}1 \\
5\end{array}$ & 0 & 0 & 4 & $\begin{array}{l}1 \\
9\end{array}$ & & \\
\hline Studia mgr & 3 & 0 & 1 & 0 & 2 & 0 & 3 & 2 & 0 & 0 & 1 & 0 & 3 & 2 & 1 & 0 & 6 & & \\
\hline
\end{tabular}

Źródło: wynik badań własnych.

Wynik poziomu istotności testu Chi - kwadrat jest mniejszy od przyjętego $(\mathrm{p}<0,05)$ co daje podstawę do odrzucenia hipotezy zerowej. Cecha badana, jaką jest wykształcenie, okazała się istotna dla wyników pomiaru. Współczynnik korelacji jest w przedziale korelacji dodatniej słabej $(0,314)$, co potwierdza małe podobieństwo odpowiedzi 
grup o różnym wykształceniu. Dodatnia korelacja wskazuje, że im wyższy jest poziom wykształcenia, tym wpływ na postrzeganie osób chorych na schizofrenię jest większy.

\section{Wpływ częstotliwości spotkań z osobami chorymi na schizofrenię na sposób ich postrzegania}

Podczas badania powyższej hipotezy podobnie jak w hipotezie I i II przeanalizowano odpowiedzi na trzy pytania (Tabela 6, Tabela 7, Tabela 8). Tym razem zbadano odpowiedzi wszystkich respondentów w odniesieniu do częstotliwości spotkań z osobami chorymi na schizofrenię. Określono korelację oraz poziom istotności między poszczególnymi grupami różniącymi się częstotliwością spotkań $\mathrm{z}$ chorymi na schizofrenię. Wyniki przedstawiono $\mathrm{w}$ poniższej tabeli 12.

Tabela 12. Analiza statystyczna wpływu częstotliwości spotkań z osobami chorymi na schizofrenię na sposób ich postrzegania.

\begin{tabular}{|c|c|c|c|c|c|c|c|c|c|c|c|c|c|c|c|c|c|}
\hline \multirow{2}{*}{$\begin{array}{l}\text { Częstotliwość } \\
\text { spotkán } \\
\text { z chorymi }\end{array}$} & \multicolumn{5}{|c|}{ Pytanie 13} & \multicolumn{5}{|c|}{ Pytanie 14} & \multicolumn{4}{|c|}{ Pytanie 20} & $\mathbf{N}$ & \multirow{2}{*}{$\begin{array}{l}\text { Wsp. } \\
\text { kore } \\
\text { lacji }\end{array}$} & \multirow{2}{*}{$\begin{array}{l}\text { Poziom } \\
\text { istotnośs } \\
\text { ci testu } \\
\text { Chi- } \\
\text { kwadrat }\end{array}$} \\
\hline & \begin{tabular}{|l|l}
$\mathrm{A}$ & $\mathrm{B}$ \\
\end{tabular} & C & \begin{tabular}{|l|} 
D \\
\end{tabular} & & $\mathbf{F}$ & A $\mathbf{E}$ & & C & D 1 & $F$ & A & & C & D & & & \\
\hline Codziennie & 90 & 0 & 1 & 0 & 0 & $3 \mid 7$ & & & 0 & 0 & 9 & 1 & 0 & 0 & 1 & & \\
\hline $\begin{array}{l}\text { Kilka razy } \\
\text { w tygodniu }\end{array}$ & $\left|\begin{array}{l}2 \\
1\end{array}\right| c$ & 3 & 1 & 6 & 0 & 7 & & & 0 & 20 & 2 & 1 & 1 & 1 & 1 & & \\
\hline $\begin{array}{l}\text { Kilka razy } \\
\text { w miesiącu }\end{array}$ & 90 & 0 & $0 \mid$ & 1 & 2 & 32 & & 5 & 0 & $1 \mid 1$ & 7 & 0 & 4 & 1 & 1 & 0,446 & 0,045 \\
\hline Raz na rok & $\begin{array}{l}1 \\
8\end{array}$ & 0 & 1 & 5 & 4 & 3 & & [ & 0 & & 7 & 0 & $\begin{array}{l}1 \\
0\end{array}$ & 1 & 8 & & \\
\hline Nigdy & 5 & 3 & 1 & 3 & 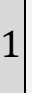 & 6 & & 3 & 0 & & 1 & & 1 & 1 & & & \\
\hline
\end{tabular}

Źródło: wynik badań własnych. 
Wynik poziomu istotności testu chi - kwadrat jest mniejszy od przyjętego $(\mathrm{p}<0,05)$, Cecha badana, jaką jest częstotliwość spotkań z chorymi na schizofrenię, okazała się istotna dla wyników pomiaru. Współczynnik korelacji potwierdził wpływ tej cechy na odpowiedzi, gdyż jego wartość znalazła się $\mathrm{w}$ przedziale korelacji dodatniej przeciętnej $(0,446)$. Dodatnia korelacja wskazuje, że im częstszy jest kontakt z chorymi na schizofrenię, tym wpływ na ich postrzeganie jest większy.

\section{Dyskusja}

\section{Hipoteza 1: $\mathrm{W}$ zawodzie pielęgniarki doświadczenie zawodowe wpływa na postrzeganie osób chorych na schizofrenię.}

Analiza badań własnych wykazała, że w zawodzie pielęgniarki cecha badana, jaką jest doświadczenie zawodowe, okazała się nieistotna dla wyników pomiaru. Brak jest związku istotnego statystycznie pomiędzy stażem pracy a postrzeganiem chorych na schizofrenię ( $p=0,0574)$. Wyznaczony współczynnik korelacji znalazł się $w$ przedziale korelacji dodatniej przeciętnej $(0,634)$, co wskazało na przeciętne podobieństwo odpowiedzi grup o różnym stażu pracy. Określając osobę chorą na schizofrenię pielęgniarki/pielęgniarze $\mathrm{z}$ rożnym doświadczeniem zawodowym najchętniej wybierali przymiotnik: normalny, dotknięty chorobą człowiek. Tylko dziewięcioro spośród 44 badanych określiło ich jako osoby nieprzewidywalne, niebezpieczne. Żadna z badanych osób nie uznała chorego na schizofrenię za potencjalnego przestępcę. Uczucia ankietowanych pielęgniarek/pielęgniarzy wobec w/w chorych opierały się najczęściej na chęci niesienia pomocy, przychylności i współczuciu. Żadna z osób nie zaznaczyła odpowiedzi fascynacja, a lęk, strach tylko 2 osoby. Jako optymalne miejsce pobytu osoby chorej na schizofrenię pielęgniarki/pielęgniarze wskazywali rodzinny dom, tylko dwie osoby umieściłyby ich w samodzielnym mieszkaniu, a trzy 
pracujące powyżej 20 lat $\mathrm{w}$ szpitalu psychiatrycznym. Ostatecznie doświadczenie zawodowe okazało się nie wpływać istotnie na postrzeganie osób chorych na schizofrenię, czego powodem może być fakt, iż w grupie przebadanych pielęgniarek/pielęgniarzy nie było osób o stażu pracy niższym niż rok, a tylko 6 osób pracowało w zawodzie mniej niż 10 lat.

W komunikacie z badań Centrum Badania Opinii Społecznej z 2008 roku, prawie w każdej z grup społeczno - demograficznych badani najczęściej pozytywnie oceniali własny stosunek do chorych psychicznie, co wiązali z doświadczeniem życiowym. Najmłodsza część badanych osób (od 18 do 24 r.ż.) była najmniej życzliwą grupą, swój stosunek do chorych psychicznie określając na obojętny. Podobnie odpowiedzieli uczniowie i studenci oznaczając niechęć częściej niż pozostali ankietowani. Wraz ze wzrostem wieku badanych obojętność ustępowała życzliwości. Również kobiety dominowały $\mathrm{z}$ tą odpowiedzią nad mężczyznami [21].

J. Żebrowska (i inni) badając 228 studentów I roku (fizjoterapii, zdrowia publicznego, pielęgniarstwa, położnictwa) studiów pierwszego stopnia, dowiodła, że 22,4\% z nich chorobę psychiczną określało jako niepełnosprawność i był to najwyższy odsetek spośród wszystkich możliwych odpowiedzi. Przy czym aż $39 \%$ ankietowanych nie miało kontaktu z takimi osobami, jednak 26\% potrafiło określić stosunek społeczeństwa do osób niepełnosprawnych jako - niedobry, a $22 \%$ jako, zły i niewłaściwy [22].

B. Mróz w swoich badaniach porównawczych dotyczących stereotypu chorych psychicznie dowiodła, że świadomość na temat problemów osób chorych psychicznie w czasie 10 - lecia nieznacznie wzrosła. Obraz samego chorego nie uległ poprawie zmieniła się jednak złożoność jego postrzegania. Pozytywnym nastawieniem do osób chorych psychicznie odznaczają się najczęściej ankietowani zaangażowani $\mathrm{w}$ czynności religijne oraz mieszkańcy ponad półmilionowych miast. Podobnie jak w komunikacie $\mathrm{z}$ badań CBOS 
z 2008 roku przychylniejszy stosunek wobec chorych prezentują kobiety niż mężczyźni [23].

Hipoteza 1. W zawodzie pielęgniarki doświadczenie zawodowe wpływa na zmianę postrzegania osób chorych na schizofrenię. Hipoteza nie została potwierdzona.

\section{Hipoteza 2: W zawodzie pielęgniarki wykształcenie wpływa na postrzeganie osób chorych na schizofrenię.}

Po analizie badań własnych udowodniono, że cecha badana, jaką jest wykształcenie, wpływa istotnie statystycznie na profil postrzegania chorych na schizofrenię. Wynik poziomu istotności testu Chi - kwadrat jest mniejszy od przyjętego $(p=0,018)$, co daje podstawę do odrzucenia hipotezy zerowej. Współczynnik korelacji znalazł się w przedziale korelacji dodatniej słabej $(0,314)$, co potwierdziło małe podobieństwo odpowiedzi grup o różnym wykształceniu. Dodatnia korelacja wskazuje, że im wyższy jest poziom wykształcenia, tym wpływ na postrzeganie osób chorych na schizofrenię jest większy. Wyższe wykształcenie bardziej różnicuje postrzeganie osób chorujących na schizofrenię. W przypadku ukończenia studiów licencjackich 14 z 19 przebadanych pielęgniarek/pielęgniarzy uznało chorującego na schizofrenię za „normalnego dotkniętego chorobą człowieka” tj. 74\%, tylko jedna za „dziwaka” - 5\%, a cztery za „osobę nieprzewidywalną i niebezpieczną" - 21\%. Podobne wyki uzyskano w przypadku pielęgniarek/pielęgniarzy, którzy ukończyli liceum medyczne.

W przypadku osób, które ukończyły studia magisterskie ten podział był bardziej wyrównany. Połowa (50\%) magistrów pielęgniarstwa określiło osobę chorą na schizofrenię, jako „normalnego dotkniętego chorobą człowieka”, którego akceptują i najchętniej umieściliby w rodzinnym domu. Pozostali, jako „dziwaka” (17\%) pomieszkującego w samodzielnym mieszkaniu oraz „osobę 
nieprzewidywalną, niebezpieczną"(33\%), siejącą strach i lęk, dla której optymalnym miejscem pobytu byłby szpital psychiatryczny.

W komunikacie z badań Centrum Badania Opinii Społecznej z 2008 roku opracowanym przez B. Wciórkę (i in.) ankietowani z wyższym wykształceniem oraz przedstawiciele kadry kierowniczej dominowali nad innymi najczęściej określając na życzliwy swój stosunek do osób chorych psychicznie [21].

E. Jackowska w swojej pracy zamieściła wyniki polskich badań CBOS na podstawie których wykazano, że osoby o niższym wykształceniu, robotnicy niewykwalifikowani mieszkańcy wsi i małych miast niekorzystnie wypowiadają się na temat chorujących na schizofrenię, używając negatywnych epitetów je określających. Jednocześnie wzrost wykształcenia zmienia profil postrzegania w/w chorych na neutralny i pozytywny. Natomiast Bąk przebadała 149 studentów I roku wieczorowych studiów psychologii, którzy określali osobę chorą psychicznie najczęściej (64-80\%) używając przymiotników: gwałtowny, nieprzewidywalny, zamknięty w sobie, nieświadomy, agresywny, zagubiony - wybierając cechy negatywne oraz wrażliwy - jako cechę pozytywną [20].

Hipoteza 2. W zawodzie pielęgniarki wykształcenie wpływa na postrzeganie osób chorych na schizofrenię. Hipoteza została potwierdzona.

\section{Hipoteza 3: Częsty kontakt $\mathrm{z}$ osobami chorymi na schizofrenię zmienia profil ich postrzegania.}

Analiza badań własnych wykazała, że cecha jaką jest częstotliwość spotkań z osobami chorującymi na schizofrenię okazała się istotna dla wyników pomiaru. Wynik poziomu istotności testu chi kwadrat jest mniejszy od przyjętego $(\mathrm{p}<0,05)$, Również współczynnik korelacji potwierdził wpływ tej cechy na odpowiedzi. Jego wartość uplasowała się w przedziale korelacji dodatniej przeciętnej $(0,446)$. 
Oznacza to, że im częstszy jest kontakt z chorymi na schizofrenię, tym wpływ na ich postrzeganie jest większy.

Studenci, którzy nie mieli kontaktu z chorymi na schizofrenię lub ocenili go na sporadyczny - „raz na rok” określali powyższych chorych na ludzi normalnych, dotkniętych chorobą, zagubionych, nieufnych, zamkniętych $\mathrm{w}$ sobie, bez powodu generujących lęk i napięcie. Jako miejsce ich pobytu wskazując rodzinny dom $(70 \%$ badanych). W tym względzie podobnie postrzegały ich pielęgniarki/pielęgniarze opiekujący się nimi na co dzień lub kilka razy w tygodniu. Inaczej sytuacja przejawiała się w aspekcie akceptacji chorujących na schizofrenię. Potwierdziło ten fakt tylko 14\% studentów, natomiast niemal dwukrotnie częściej pielęgniarki/pielęgniarze (27\%). Jednocześnie strach w odniesieniu do tych osób odczuwało aż 14\% studentów, a niemal trzykrotnie mniej pielęgniarek/pielęgniarzy (5\%). Życzliwość wobec powyższych chorych w obu grupach oscylowała na poziomie 38-39\% badanych. Natomiast obojętność dominowała w grupie studentów (22\%) oraz 9\% pielęgniarek/pielęgniarzy. Również jako kolejne pod względem procentowym miejsce stałego pobytu osób chorujących na schizofrenię studenci wymieniali szpital psychiatryczny $(24 \%$ badanych) lub zamkniętą placówkę opieki medycznej (6\% respondentów). Natomiast bardziej zróżnicowanie odpowiadały pielęgniarki/pielęgniarze: szpital psychiatryczny wskazało 9\% osób, samodzielne mieszkanie 5\% respondentów, zamkniętą placówkę opieki medycznej $16 \%$ badanych.

B. Mróz dowiodła w swoich badaniach, że obawa o własne zdrowie psychiczne lub osobista znajomość chorego psychicznie odczucie obojętności wobec chorującego psychicznie przekształca w życzliwość [23].

Podobne wyniki otrzymał Nortd (i in.), który w raporcie z badań 1743 dorosłych obywateli, w tym kilku grup zawodowych: lekarzy psychiatrów, pielęgniarek, fizjoterapeutów i pracowników społecznych, zamieścił swoje wyniki. Autor dowiódł, że badani 
z ogólnej populacji w ponad 19\% pozbawiliby chorych psychicznie możliwości głosowania, natomiast w 65\% możliwości zdobycia licencji kierowcy. Odpowiedzi psychiatrów jako grupy zaangażowanej w leczenie uplasowały się na poziomie 3\% i 29\%. Również pielęgniarki, mając częstszy kontakt $\mathrm{z}$ chorymi psychicznie odpowiadały mniej restrykcyjnie (2,8\% i $46 \%$ badanych) [20].

Abranos (2008r) badając chorwacką młodzież w wieku 17-18 lat porównał ich stygmatyzującą postawę wobec schizofrenii, depresji i zespołu stresu pourazowego. Najbardziej negatywne stanowisko młodzież przyjmowała $\mathrm{w}$ stosunku do chorych na schizofrenię zupełnie nie akceptując ich jako małżonka, współlokatora, czy osoby pracującej zawodowo. Uczestnicząca w badaniach populacja ostatniej klasy szkoły medycznej uzyskała wskaźnik niższy od licealistów i uczniów szkoły ekonomicznej, aczkolwiek również negatywny. Autor sugerował, że na wynik pomiaru miał wpływ bezpośredni kontakt tej grupy z pacjentami leczonymi w oddziale psychiatrycznym [20].

Hipoteza 3. Częsty kontakt z osobami chorymi na schizofrenię zmienia profil ich postrzegania. Hipoteza została potwierdzona.

\section{Wnioski}

1. W zawodzie pielęgniarki doświadczenie zawodowe nie ma istotnego wpływu na zmianę postrzegania osób chorych na schizofrenię.

2. W zawodzie pielęgniarki poziom wykształcenia ma istotny wpływ na postrzeganie osób chorych na schizofrenię.

3. Częstotliwość spotkań z chorymi na schizofrenię ma istotny wpływ na sposób ich postrzegania.

\section{Zalecenia dla praktyki pielęgniarskiej}


Prowadzone badania pozwalają na analizę postrzegania osób chorych na schizofrenię przez studentów studiów licencjackich na kierunku pielęgniarstwo oraz pielęgniarki czynne zawodowo.

Istotne znaczenia dla chorych na schizofrenie ma wsparcie i poczucie bezpieczeństwa otrzymywane od społeczeństwa. Ma to bezpośredni wpływ na przebieg terapii oraz efekty prowadzonego leczenia.

Studenci pielęgniarstwa oraz pielęgniarki powinny zwracać szczególną uwagę na komunikację $\mathrm{z}$ pacjentami chorymi na schizofrenię. Tym samym budowane zaufanie poprawia relację personel - pacjent i wzmaga efekty prowadzonego leczenia, a także łagodzi konsekwencje choroby.

\section{Bibliografia / Bibliography:}

1. De Barbaro B., Ostoja - Zawadzka K., Cechnicki A.: Możesz pomóc poradnik dla rodzin pacjentów chorych na schizofrenię i zaburzenia schizotypowe. Wydawnictwo Uniwersytetu Jagiellońskiego, Kraków 2005: 131-141.

2. Ostrzyżek A., Marcinkowski J.: Jakość życia a doświadczanie schizofrenii, Hygeia Public Health 2014, 49(4): 679-684.

3. Tyszkowska M., Jarema M.: Między zdrowiem a schizofrenią. Psychiatria Polska 2013, 47(4): 587-597.

4. Furgał M.: Psychozy schizofreniczne $\mathrm{i}$ z kręgu schizofrenii. Psychiatria podręcznik dla studiów medycznych. Heitzman J. (red). Wydawnictwo Lekarskie PZWL, Warszawa 2007: 79-92.

5. Górna K.: Opieka nad pacjentem ze schizofrenią. Podstawy pielęgniarstwa psychiatrycznego. Wilczek-Rużyczka E. (red): Wydawnictwo Czelej, Lublin 2007: 135-137.

6. Krzystanek M.: Schizofrenia, zaburzenia typu schizofrenii (schizotypowe) i urojeniowe. Psychiatria. Podręcznik dla studentów 
pielęgniarstwa. Krupka-Matuszczak I., Matuszczak M. (red). Wydawnictwo Śląski Uniwersytet Medyczny, Katowice 2007: 35-40.

7. Rybakowski F.: Schizofrenia i inne zaburzenia psychotyczne. Podstawy kliniczne. Pielęgniarstwo psychiatryczne. Górna K., Jaracz K., Rybakowski J (red), Wydawnictwo Lekarskie PZWL, Warszawa 2012: 195-202.

8. Źródło internetowe: http:/www. Raport Polskiego Towarzystwa Psychiatrycznego „Schizofrenia- perspektywa społeczna. Sytuacja w Polsce". Styczeń 2014, dostęp Styczeń 2016: 1-37.

9. Kurowska K., Kaczmarek M.: Rola wsparcia i poczucia koheracji w zmaganiu się ze schizofrenią. Psychiatria i Psychologia Kliniczna 2013, 13(4): 239-249.

10. Skorupska A., Czyżowicz K.: Deficyty funkcjonowania społecznego w schizofrenii - przegląd literatury. Family Medicine \& Primary Care Review 9/2007: 1060-1063.

11. Siuta J. (red): Słownik Psychologii. Wydawnictwo Zielona Sowa, Kraków 2005: 263-264.

12. Śnieciński J. (red): Encyklopedia Pedagogiczna XXI wieku, Tom 4, Wydawnictwo Akademickie ŻAK, Warszawa 2012: 347-348.

13. Jaromin M.: Chory psychicznie w oczach Polaków. Magazyn o Zdrowiu Psychicznym - Psyche Info 1/2006, Wydawnictwo WIATR: 20-21.

14. Szpunar M.: Odgrodzeni od świata poprzez bariery mentalne. Społeczne stereotypy i dystanse wobec chorych psychicznie. Pod wielkim dachem nieba. Granice, migracje i przestrzeń we współczesnym społeczeństwie. Muszyński W, Sikora E. (red.) Wydawnictwo Adam Marszałek, Toruń 2009: 309-320.

15. Całek A.: Internet jako sposób na tabu choroby psychicznej. Kultura Popularna 4/2012: 128-139. 
16. Źródło internetowe: http:/www.cbos.pl. Opinia publiczna o chorobach psychicznych. Raport $\mathrm{z}$ badani ilościowego typu „Omnibus” dla Instytutu Praw Pacjenta i Edukacji Zdrowotnej. Warszawa 2007, dostęp: styczeń 2016: 3-13.

17. Rasmus P., Nowaczyńska E., Stetkiewicz-Lewandowicz A.: Wykluczenie społeczne i dyskryminacja przewlekle chorych psychicznie $\mathrm{w}$ województwie łódzkim. Polski Merkuriusz Lekarski 2013, XXXV: 5-11.

18. Tyszkowska M., Podogrodzka M.: Stygmatyzacja na drodze zdrowienia $\mathrm{w}$ chorobach psychicznych - czynniki bezpośrednio związane w leczeniem psychiatrycznym. Psychiatria Polska 2013, 47(6): 1011-1022.

19. Dziwota E.: Stygmatyzacja osób chorych psychicznie. Current Problems of Psychiatry 2014, 15(1): 18-23.

20. Jackowska E.: Stygmatyzacja i wykluczenie społeczne osób chorujących na schizofrenią - przegląd badań i mechanizmy psychologiczne. Psychiatria Polska 2009, 43(6): 655-670.

21. Źródło internetowe: http:/www.cbos.pl. Osoby chore psychicznie w społeczeństwie - komunikat z badań. Centrum Badania Opinii Społecznej, Warszawa 2008, dostęp: styczeń 2016: 3-18, 25-26.

22. Żebrowska J., Krajewska-Kułak E., Łukaszuk C.: Postawy studentów Wydziału Nauk o Zdrowiu wobec osób niepełnosprawnych. Problemy Pielęgniarstwa 2012, 20(4): 487-496.

23. Mróz B.: Dyferencjał semantyczny w badaniu stereotypu chorych psychicznie - badania porównawcze po 10 latach. Psychiatria Polska 2014, 48(6): 1269-1281. 